\title{
On The Responsibility Of MNCs: Some Reflections
}

George Andreopoulos, City University of New York

Giuliana Campanelli Andreopoulos, William Paterson University

Alexandros Panayides, William Paterson University

\begin{abstract}
The general debate on MNC and their responsibility is fraught with misperceptions. The purpose of this paper is to place the issue of accountability into a proper perspective. This would entail a clarification of the following three issues: type of sector of MNCs whose activities have generated accountability-related issues; the nature of the interests that they represent; and the types of violations which are involved. In addition, the paper will provide a set of policy recommendations on ways of enhancing accountability.
\end{abstract}

Keywords: multinational corporations, accountability, human rights

\section{INTRODUCTION}

63

ne of the most important phenomena of the latter half of the twentieth century in international business was the emergence of the multinational corporation (MNC). The many different definitions of MNCs usually rest on one of the following common characteristics: (a) company headquarters far removed from the country where the activity occurs, (b) foreign sales representing a high proportion of total sales, and (c) stock ownership and management that are multinational in character. Perhaps the most common definition of a $\mathrm{MNC}$, however, is that it is a company that manages and controls facilities in at least two countries.

The phenomenon of MNCs is not new, instead tracing back to the late $18^{\text {th }}$ century when firms like the British, Dutch, and French East Indian Companies sought raw materials overseas. The modern-day counterparts of these raw material-seeking firms are the multinational oil and mining companies, as recent advances in transportation and communications technology increased the feasibility of global production, enabling MNCs to grow rapidly over the last sixty years.

There is a vivid debate on MNCs in particular on their violations of legal and ethical rules and regulations and their accountability. However, this debate is fraught with misperceptions and the purpose of this paper is to place the issue of violations and accountability on a proper perspective. Before we proceed with the issues that this paper will address, a note on accountability is in order. Accountability, in both its regulatory and voluntary dimensions, has become a major issue in global governance. It is by definition a relational concept. At the most basic level, an agent is responsible for some act or a failure to act in ways that are consistent with certain accepted standards of behavior, as well as to someone or some institutional entity. Accountability is premised on the idea that some actors have a right to hold others to such standards, to judge them in accordance to these standards, and to sanction them in cases of failure to uphold them (Grant and Keohane, 2005). For the purposes of this paper, the notion of accountability refers to the responsibilities incurred by MNCs vis-à-vis those entities affected by their conduct (shareholders, customers, suppliers, employees, communities within which they operate) in order to ensure that the conduct in question is consistent with internationally recognized rules and standards.

The paper is structured as follows: section two discusses the most common misperceptions about the type of sectors of MNCs, the types of violations as well as the recommendations for enhancing accountability and lastly section three provides summary and concluding remarks. 


\section{COMMON MISPERCEPTIONS}

In the literature as well as in the media on MNCs' there are some common ideas that everybody takes for granted while in our opinion represent serious misperceptions. Among the most prevalent misperceptions are the following:

- $\quad$ The majority of the top non-financial corporations are in the manufacturing sector

- $\quad$ Most of the violations committed by MNCs are in the field of labor rights and standards

- $\quad$ The main way to strengthen accountability is further legislation, both domestically and internationally.

In what follows we will analyze each of these misperceptions.

\section{A. Type Of Sectors}

A simple investigation of MNCs shows quite a different picture with respect to the first misperception. A substantial share of MNCs is operating in what we can define as the resource-extraction sector, i.e., petroleum, natural gas, water, mining and quarrying, and metal and metal products.

Table 1

The world's top ten non-financial MNCs ranked by total sales, 2004 (billions of dollars)

\begin{tabular}{|l|c|c|c|c|c|}
\hline & Corporation & Home Country & Industry & Total Sales & $\begin{array}{c}\text { \% of Foreign to } \\
\text { Total Sales }\end{array}$ \\
\hline 1 & Exxon Mobile & US & Petroleum & 291.2 & 69.7 \\
\hline 2 & British Petroleum & UK & Petroleum & 285.1 & 81.5 \\
\hline 3 & Royal Dutch/Shell & Netherlands & Petroleum & 265.2 & 64.2 \\
\hline 4 & General Motors & US & Motor vehicles & 193.5 & 30.6 \\
\hline 5 & Ford & US & Motor vehicles & 171.6 & 41.6 \\
\hline 6 & Toyota & Japan & Motor vehicles & 171.5 & 60 \\
\hline 7 & General Electric & US & Electronic & 152.9 & 37.2 \\
\hline 8 & Total & France & Petroleum & 152.4 & 80.9 \\
\hline 9 & Vodafone & UK & Telecommunication & 62.5 & 85.2 \\
\hline 10 & France Telecom & France & Telecommunication & 58.6 & 41.4 \\
\hline
\end{tabular}

Source: UNCTAD/Erasmus University database

As table 1 show, if we take the world's top ten non-financial MNCs the presence of the resource-extraction sector is overwhelming; their total sales amount to 993.9 billion dollars which represents more than $55 \%$ of the grand total. If we consider the next ninety non-financial MNCs ranked by total sales, approximately one-third of the total sales are represented by the resource-extraction sector MNCs.

In addition, in the resource-extraction sector foreign demand accounts on average for $75 \%$ of total sales which implies that they are more international oriented. On the other hand for the manufacturing based sector the foreign sales account only for $44 \%$ of the total sales.

For the MNCs whose activities are in resource-extraction sector the main reason to be global is strategic. Their main purpose is to guarantee a constant and stable supply of minerals, metals and energy resources to their home countries. Given the fact that natural resources are not mobile MNCs are willing to move into areas with high level of regional conflicts (Berman, 200). The obvious example is the oil industry. Particularly, in 2005, 74\% of the oil supply in the American economy came from MNCs operating in the following six countries: Canada, Mexico, Saudi Arabia, Venezuela, Nigeria and Iraq. 


\section{B. Types Of Violations}

As stated above, the second common misperception about MNCs is that the main violations are in the area of labor rights and standards. One of the most common criticisms of MNCs is that they pay inadequate wages and consequently exploit the labor force in developing countries. In addition, MNCs are accused of violating labor rights by exploiting child labor, imposing extremely long working hours without paying insurance and benefits. Needless to say, these are serious violations; however they constitute a fraction of the alleged violations MNCs engage in. MNCs have routinely engaged in environmentally destructive practices. A series of environmental disasters have highlighted this aspect of MNC activity; among them the Bhopal disaster in India, and the case brought by asbestosis victims in South Africa against the UK parent of a group of mining companies (Zerk, 2006). In addition, MNCs are among the main "culprits" in the consumption of fossil fuels; as a result, many of them are top ranked in the Toxic 100 corporate polluters in the United States. Moreover, abusive marketing practices targeting consumers in developing countries have highlighted another realm of questionable MNC conduct; in particular, the marketing of tobacco products, as well as that of baby milk products. The latter led to a transnational campaign against Nestle orchestrated by the International Baby Food Action Network (Keck and Sikkink, 1998). Last, but not least, beginning in the mid-1970s, the public became increasingly aware of MNC meddling in the domestic affairs of developing countries; meddling primarily manifested in the massive and systematic bribing of government officials. It was this type of conduct that placed, among other things, the issue of MNC accountability on the UN's agenda with the adoption of the UN Code of Conduct for Transnational Corporations (Gunderson, 2006).

While MNCs do have some strong defenders of their record, especially on issues pertaining to labor rights and standards (Bhagwati, 2004), few would question the proposition that, given the range of violations involved, MNC accountability has emerged as a major world order issue.

Having shown above that the resource-extraction sector represent an important component of MNCs the next question is the following: What are, more specifically, some of the violations more often associated with MNCs in this sector and what are the instruments that incorporate the relevant standards? (The list that follows is by no means exhaustive and some of these violations are not confined to MNCs in the resource-extraction sector).

Most of the violations can be clustered under MNC complicity in abuses that are committed by governments and non-state armed groups especially in communities that lack adequate institutional mechanisms for human rights protection (Gunderson, 2006). In particular, such abusive conduct can include violations of the following rights:

\section{Rights at stake}

- $\quad$ Non-discrimination

- Life

- $\quad$ Liberty and security of person

- $\quad$ Freedom of opinion and expression

- $\quad$ freedom of association

- $\quad$ just and favorable conditions of work

- health

- $\quad$ self-determination

\section{Instruments/Provisions}

UDHR (article 2); ICCPR (article 2); ICESCR (article 2)

UDHR (article 3); ICCPR (article 6)

UDHR (article 3); ICCPR (article 9)

UDHR (article 19); ICCPR (article 19)

UDHR (article 20); ICCPR (article 22)

UDHR (article 23); ICESCR (article 7)

UDHR (article 25); ICESCR (article 12)

ICCPR (article 1); ICESCR (article 1)

(UDHR=Universal Declaration of Human Rights; ICCPR= International Covenant on Civil and Political Rights; ICESCR= International Covenant on Economic, Social and Cultural Rights. In addition to these global instruments, more specialized (geographically as well as thematically) instruments complement and, in many cases, supplement and extend parallel substantive norms of the global regime. For example, many of the above mentioned rights are included in regional instruments such as the European Convention for the Protection of Human Rights and 
Fundamental Freedoms, the American Convention on Human Rights and the African Charter on Human and Peoples' Rights. Moreover, thematically focused regimes such as that of the International Labor Organization (ILO) include conventions that cover issues pertaining to freedom of association, forced labor, migrant workers, discrimination in employment, and equality of remuneration, among others).

One MNC case that has highlighted many of the aforementioned issues, primarily because of alleged complicity with the government of the country in abuses committed against the local population, was that of Shell in Nigeria. The Nigerian Shell subsidiary, Shell Petroleum Development Corporation (SPDC) was implicated in a series of human rights violations committed against the Ogoni people in southeastern Nigeria culminating with the arrest and execution of Ken Saro-Wiwa and another local activist. In a petition filed with the African Commission on Human and Peoples' Rights (an organ of the African Charter on Human and Peoples' Rights) by two NGOs on behalf of the Ogoni people, the Commission found Nigeria to have breached its obligations under the Charter. In particular, the Nigerian government was found to have violated, among other things, the Charter's nondiscrimination provision (article 2); the right to life (article 4); the right to property (article 14); the right to health (article 16); the right of peoples to freely dispose of their wealth and natural resources (article 21); and the right of peoples to a "general satisfactory environment favorable to their development" (article 24). While the Commission held the Nigerian government responsible for not enforcing its laws, most of the violations resulted from actions that involved the Nigerian National Petroleum Development Company in a consortium with the SPDC (African Commission on Human and Peoples' Rights, 2002). While the Commission lacks enforcement powers, the importance of this case should not be underestimated. The case involved serious claims against a major MNC by using the mechanisms and procedures provided by a regional regime in the global south.

\section{Recommendations For Enhancing Accountability}

A lot of the discussion on promoting accountability in the context of the often used term corporate social responsibility (CSR) focuses on the advantages and disadvantages of voluntary vs. mandatory measures. However, as several analysts have argued, the voluntary vs. mandatory debate is misguided primarily for for two reasons: first because many issues related to CSR are already regulated (typical examples include consumer protection, and workplace health and safety); second, because this divide is premised on a simplistic view of the nature of the law and its role in guiding human behavior. Very often, especially in situations where the law is unclear, or the relevant legal standards are not easily enforceable, parties interpret their legal obligations in light of a variety of non-legal factors, such as corporate culture or transnational advocacy (Zerk, 2006). Two good examples of the interface between CSR and the law are the OECD Guidelines for Multinational Enterprises (2000) and the United Nations Global Compact (2000). Concerning the OECD Guidelines, in the section entitled Concepts and Principles, the Guidelines stipulate that while their observance by enterprises "is voluntary and not legally enforceable," "they (i.e. the guidelines) provide principles and standards of good practice consistent with applicable laws" (from other sections of the guidelines, it is clear that the term applicable laws refers to both domestic and international ones). In a similar vein, the Global Compact's ten principles are derived from the Universal Declaration of Human Rights, the International Labour Organization's Declaration on Fundamental Principles and Rights at Work, the Rio Declaration on Environment and Development, and the United Nations Convention Against Corruption.

Thus any constructive discussion on accountability should avoid the pitfalls of the voluntary vs. mandatory debate. Instead, the focus should be on the desired objectives, namely to ensure corporate conduct consistent with international rules and standards. In cases where violations are committed, the twin tasks at hand are the provisions of appropriate remedies, and the adoption of measures to ensure that such violations do not recur. The desired objective will determine the method, the venue and the relevant stakeholders. In recent years, the landscape of MNC-related accountability has broadened: it includes the use of domestic courts (for example, the use of the US Alien Torts Claim Act to bring lawsuits before federal courts against companies for alleged human rights violations), of international/regional human rights mechanisms (for example, the African Commission on Human and Peoples' Rights in the case against Nigeria), and of different codes, general or issue-specific (for example, the United Nations Global Compact, the OECD Guidelines for Multinational Enterprises, and the ILO Tripartite Declaration of Principles concerning Multinational Enterprises and Social Policy). Several of these accountabilityrelated cases have featured MNCs involved in the resource-extraction sector. In addition, the universe of relevant 
actors has clearly expanded to include transnational activist networks which have been instrumental in effective naming and shaming campaigns and in occasionally mobilizing broader constituencies for consumer boycott campaigns. While a lot remains to be done, in promoting accountability the emphasis should be placed on the more effective tailoring of means to ends rather than on ritualistic calls for more legislation.

\section{CONCLUSIONS}

The purpose of this paper was to place the issue of violations and accountability of MNCs on a proper perspective. The main conclusions of the paper are the following three: First, a substantial share of the top nonfinancial MNCs is operating in the resource-extraction sector. Second, in addition to labor-related violations MNCs are engaged in environmentally destructive practices and abusive market practices targeting consumers. Moreover, they have been directly and indirectly responsible for the commission of abuses by governments and armed groups, particularly against communities lacking adequate institutional mechanisms for human rights protection. Third, any constructive discussion on accountability should avoid the pitfalls of the voluntary vs. mandatory debate but focus on the desired objectives. The emphasis should be placed on the more effective tailoring of means to ends, rather than on ritualistic calls for more legislation.

\section{REFERENCES}

1. African Commission on Human and Peoples' Rights, Decision Regarding Communication 155/96 (Social and Economic Rights Action Center/Center for Economic and Social Rights v. Nigeria). Case No. ACHPR/COMM/A044/1. May 27, 2002.

2. Berman, Jonathan, Boardroom and Bombs: Strategies of Multinational Corporations in Conflict Areas, Making Foreign Policy, vol. 22 (3), 2000.

3. Bhagwati, Jagdish, Do Multinational Corporations Hurt Poor People? The American Enterprise Online, June 2004.

4. Grant, Ruth and Robert O. Keohane, Accountability and Abuses of Power in World Politics, American Political Science Review, vol. 99 (1), 2005.

5. Gunderson, James L. Multinational Corporations as Non-State Actors in the Human Rights Arena, in George Andreopoulos, Zehra F. Kabasakal Arat, and Peter Juviler (eds.), Non-State Actors in the Human Rights Universe. Kumarian Press, 2006.

6. Keck Margaret and Kathryn Sikkink, Activists beyond Borders: Advocacy Networks in International Politics. Cornell University Press, 1998.

7. United Nations Conference on Trade and Development, www.UNCTAD.org

8. Zerk, Jennifer, Multinationals and Corporate Social Responsibility. Limitations and Opportunities in International Law. Cambridge University Press, 2006. 
NOTES 